\title{
Assessment of $\mathrm{PM}_{2.5}$ Chemical Composition and Air Quality Monitoring: Implications of Air Pollutants Emissions from a Night Market in Kaohsiung City, Taiwan
}

\author{
Kassian T.T. Amesho ${ }^{1}$, Yuan-Chung Lin $^{1,2^{*}}$, Zhou-Wei Gong ${ }^{1}$, Feng-Chih Chou ${ }^{1}$, \\ Pei-Cheng Cheng ${ }^{1,2}$, Tsu-Nai Wang ${ }^{3}$, Pei-Shih Chen ${ }^{3}$, Kang-Shin Chen ${ }^{1,2}$, \\ Ken-Lin Chang ${ }^{1}$, Chien-Hung Lee ${ }^{3}$ \\ ${ }^{1}$ Institute of Environmental Engineering, National Sun Yat-sen University, Kaohsiung 804, Taiwan \\ ${ }^{2}$ Center for Emerging Contaminants Research, National Sun Yat-Sen University, Kaohsiung 804, \\ Taiwan \\ ${ }^{3}$ Department of Public Health, College of Health Sciences, Kaohsiung Medical University, \\ Kaohsiung 807, Taiwan
}

\section{ABSTRACT}

There are around 300 night markets in Taiwan, and they have been drawing an increasing number of tourists in recent years. As a result, public awareness over air quality in the night markets has grown tremendously. In response to this, a specific night market in Kaohsiung City was chosen for this study in order to characterize the existing air quality in and around the night markets. In this present study, we employed an Industrial Source Complex Short-Term (ISCST3) air quality model for the simulation of $\mathrm{PM}_{2.5}$ diffusions. The model as a technique can simulate the pollutants emissions, diffusions, transportation, and pollution sources in specific areas and subsequently evaluate the influence between the source and the receiver. Therefore, we compared pollutants emissions data from several air quality monitoring stations with our sampling data of three different sampling sites in Kaohsiung City. The findings of this study showed that the average concentration of $\mathrm{PM}_{2.5}$ was in the range of 29-61 $\mu \mathrm{g} \mathrm{m}^{-3}$ during opening hours of the night market, whereas the average concentration of $\mathrm{PM}_{2.5}$ range was between $22-38 \mu \mathrm{g} \mathrm{m}^{-3}$ before the night market opening hours. The concentration of metallic elements ( $\mathrm{ME})(\mathrm{Mg}, \mathrm{Na}, \mathrm{Cr}$, $\mathrm{Mn}, \mathrm{Fe}, \mathrm{Cu}, \mathrm{Al}, \mathrm{Ba}, \mathrm{Cd}, \mathrm{Pb}$ and $\mathrm{Ca}$ ) was determined with the support of Inductively Coupled Plasma Optical Emission Spectroscopy (ICP-OES). During the night market opening hours, the result disclosed that the ME concentrations in $\mathrm{PM}_{2.5}$ was in an increasing order as follows: $\mathrm{Na}>\mathrm{Fe}>\mathrm{Al}$ $>\mathrm{Ca}$. With respect to the concentration of carbonaceous species, our results showed that the highest total carbon (TC) concentration was found to be $6.52 \mu \mathrm{g} \mathrm{m}^{-3}$ during the downwind sampling interval. The highest elemental carbon (EC) and organic carbon (OC) concentration were found to be $6.53 \mu \mathrm{g} \mathrm{m}^{-3}$ and $2.70 \mu \mathrm{g} \mathrm{m}^{-3}$ of the $\mathrm{PM}_{2.5}$ concentration, respectively. This study's findings have significant consequences for Taiwan policymakers and urban planners, particularly those responsible for coordinating environmental protection and economic development in cities. Therefore, policy actions to abate urban air pollution can be attained on diverse governing echelons, resulting in synergistic effects such as a reduction in climate change impacts.

Keywords: Night market, $\mathrm{PM}_{2.5}$ emissions, Metallic elements concentrations, Air quality monitoring, Pollutants emissions, ISCST3 model

\section{INTRODUCTION}

According to the World Urbanization Prospect 2018 Revision, Asia and Africa's megacities are expected to experience a population rise of over $90 \%$ by 2050 . Along with the increase in 
population, cities economic growth activities have increased pollution levels from many industries (Jiang et al., 2021; Kumari and Toshiwal, 2020). Thus, environmental pollution has become a severe concern due to the effects of tremendous population expansion on the environment, as well as unregulated urbanization, industry, and automation. The most evident impact is that air quality is deteriorating (Kanawade et al., 2020; Hashim et al., 2021).

According to the Taiwan Environmental Protection Agency's air quality monitor, Kaohsiung City has by far the greatest ratio of poor air quality days to the total monitored days in Taiwan. In the heavily inhabited City of Kaohsiung, some of the considerable population concentrations are situated in the vicinity of several night markets. In the meantime, the number of night markets has exploded in recent years, attracting an increasing number of visitors. The night market is a very crowded outdoor cooking setting where many residents and visitors spend a significant amount of time. Indeed, the night market is an important part of Taiwan society and a distinctive venue that Taiwanese people are thrilled about. Notwithstanding that, food stalls in night markets, on the other hand, generally use fans or exhaust hoods to discharge or release their cooking fumes onto neighboring occupied places or directly above market streets. Excellent air quality at night markets not only improves the experience of market visitors, but it also safeguards market personnel and customers from exposure to detrimental air contaminants.

The night market industry has attracted numerous stalls and people around Taiwan, and hence has the ability to boost economic development. According to earlier figures, Taiwan has a large number of night markets, with over 300 operating in various locations across the island. Night markets are regarded as an integral element of Taiwanese culture (Sun et al., 2012; Chen et al., 2014). The majority of Kaohsiung City's neighborhoods are close to night markets, which attract thousands of people every day (Zhao et al., 2011; Chen et al., 2014; Liao, 2017). As a result, the levels of air pollution in the vicinity of these night markets should be evaluated, as they may pose major health risks.

Among air pollutants that are being researched nowadays, the current research trend is particularly focused on particulate matter (PM) in two size fractions, namely; $\mathrm{PM}_{2.5}$ and $\mathrm{PM}_{10}$. The primary sources of $\mathrm{PM}_{2.5}$ include vehicle exhausts, soil dust, road dust, biomass burning, fossil fuel combustion, metal processing, and other anthropogenic activities (Lin et al., 2020a, b; 2019; Huang et al., 2020; Song et al., 2021). $\mathrm{PM}_{10}$ refers to atmospheric particles with aerodynamic diameters less than or equal to $10 \mu \mathrm{m}$, which are one of the most important pollution indicators used to characterize air quality (Canha et al., 2019; Vu et al., 2019; Mahato et al., 2020). In addition to the primary sources on $\mathrm{PM}_{2.5}$, cooking methods have a huge impact on the amount of air pollutants emitted into the atmosphere. However, several researchers have reported the amount of air pollutants $\left(\mathrm{PM}_{10}, \mathrm{PM}_{2.5}, \mathrm{NO}_{\mathrm{x}}\right.$, and $\mathrm{CO}$ ) emitted from the combustion of charcoal (Huang et al., 2016; Hu et al., 2021; Vicente et al., 2018).

It is a common knowledge that atmospheric fine particulate matter pollution has been recognized as a serious public health concern nowadays. $\mathrm{PM}_{2.5}$ is a kind of fine suspended particulate, and it has a vast surface area, making it an excellent transporter of metallic elements (ME) and heavy metals alike (Sun et al., 2019; Jiang et al., 2019). The long-term exposure to $\mathrm{PM}_{2.5}$ has connection with several health issues such as cardiovascular disease and lung cancer (Wei et al., 2015; Mcguinn et al., 2019). In relation to the present study, the night markets opening hours could be one of the major $\mathrm{PM}_{2.5}$ emitted sources. Studies have indicated that air pollutants emitted from cooking activities have detrimental effects on human health (Salje et al., 2014; Stabile et al., 2015).

With respect to $\mathrm{PM}_{10}$, the source of $\mathrm{PM}_{10}$ particle could be divided roughly into two; from the natural occurrence (e.g., dust storms, slats, pollen, and volcanoes) and those that are related to human activities (e.g., power generation plants, transportation, incinerators, and domestic heating) (Dai et al., 2018; Uroš et al., 2019; Chen et al., 2020: Mohd Nadzir et al., 2020). Furthermore, $\mathrm{PM}_{10}$ is one of most crucial indexes of air quality monitoring (Liu at et al., 2020; Xu et al., 2020), due to the fact that, the main composition of $\mathrm{PM}_{10}$ is inorganic ions, organic pollutants, heavy metal elements, bacterial, viruses, and others harmful substances (Mesquita et al., 2014). Due to the fact that, $\mathrm{PM}_{10}$ has a small size; it could enter the human body via the respiratory tract, digestive tract, and skin. According to epidemiological studies, long-term exposure to high PM10 concentration could cause extensive damage to human body even cancerous changes in the respiratory, cardiovascular, immune, and endocrine systems (Rodopoulou et al., 2014; Huang et al., 2017; Carugno et al., 2018; Gondalia et al., 2019). 
Carbon is one of the most abundant components in the atmospheric PM, accounting for roughly $20-60 \%$ of $\mathrm{PM}_{2.5}$ concentration and primarily taking the forms of organic carbon (OC) and elemental carbon (EC). Atmospheric EC is emitted directly from primary human sources (Cui et al., 2017), whilst OC can be emanated directly from sources such as primary particulates and secondary OC, which are formed by chemical reactions in the atmosphere with low vapor pressure. Particulate matter's OC and EC play important roles in global climate change, visibility deterioration, and human health (Lin et al., 2020).

$\mathrm{PM}_{2.5}$ has a huge surface area, making it a potential transporter of ME, heavy metals, germs, and viruses (Jiang et al., 2019; Sun et al., 2019), which can be breathed and absorbed by the alveoli or enter other organs by lung aeration, potentially causing asthma, bronchitis, and cardiovascular disorders (McGuinn et al., 2019; Liu et al., 2016). Several studies on heavy metals as $\mathrm{PM}_{2.5}$ components and their origins have been conducted in countries such as China, Denmark, Turkey, and France (Hvidtfeldt et al., 2019; Jiang et al., 2019).

Public concern over the air quality in the night markets has dramatically increased over the past few years. While few studies have been focused on the air quality in the night markets, we decided to probe the situation of air indexes $\left(\mathrm{PM}_{10}, \mathrm{PM}_{2.5}, \mathrm{SO}_{2}, \mathrm{NO}_{\mathrm{x}}\right.$ and $\left.\mathrm{CO}\right)$, particularly during the night market opening and non-opening hours. This is an attempt to investigate the air quality and implications of air pollutants emissions from the night market activities, such as cooking and road traffic in the surroundings.

To simulate spatial variations in air pollution concentrations, a variety of air diffusion models have been used. This is due to the fact that they specifically consider transmission and pollutant variations in the environment, air diffusion models are appropriate for simulating $\mathrm{PM}_{2.5}$ concentrations in the air. They also have strong descriptive capacity for time variations (Lin et al., 2021). Diffusion models that are commonly used include the steady-state Gaussian plume, Lagrangian-based trajectory, and grid models based on grid division. Popular diffusion models comprised of AERMOD, developed by the American Meteorological Society in conjunction with U.S. Environmental Protection Agency (U.S. EPA) (Rzeszutek et al., 2017); industrial source complex short-term model (ISCST3), developed by U.S. EPA (Hanna et al., 2001; Wesely et al., 2002); community multiscale air quality (CMAQ) model developed by U.S. EPA (Binkowski and Roselle, 2003); CALPUFF developed by Exponent, Inc., USA (Levy et al., 2002; Scire et al., 2000); and the ALOHA model developed by U.S. EPA explicitly for the diffusion hazardous materials. These models have a variety of benefits and drawbacks, and they have been frequently utilized to simulate and compare air pollutant transmission in diverse studies (Asadi et al., 2017; Butland et al., 2020). Some of the most often used air diffusion models are listed in Table 1.

The ISCST3 model is a steady-state Gaussian plume model that may be used to assess pollution concentrations released by various industrial park sources. ISCST3 can simulate pollutant particle sedimentation; point, line, surface, and volume emission sources; distance role from wind direction; point source partition; and permits other topographic modifications. The Gaussian plume model is based on the premise that the vertical plume centerline concentration distribution is Gaussian, with the wind field direction serving as the plume centerline and maximum plume concentration flowing along it (Lee et al., 2018). The ISCST3 model can handle a variety of sources, including point, volume, area, and open pit sources. It can assess pollution levels released by various sources in industrial parks. ISCST3 has been proved in numerous studies to be a better model for simulating the dispersion of air contaminants, notably from industrial sources (Bajoghli, 2019; Karuna et al., 2017; Prakash et al., 2017).

Table 1. Commonly used air diffusion models (Lin et al., 2021).

\begin{tabular}{lll}
\hline Model Name & Developer & Type \\
\hline AERMOD & U.S. EPA & Gaussian plume model \\
ISCST3 & U.S. EPA & Gaussian plume model \\
CMAQ & U.S. EPA & Photochemical Modeling/Grid \\
CALINE4 & California Department of Transportation & Gaussian plume model \\
CALPUFF & Exponent, Inc., USA & Gaussian plume model \\
HYSPLIT & National Oceanic and Atmospheric Administration (NOAA) & Trajectory \\
ALOHA & U.S. EPA & Hazard chemical modeling \\
\hline
\end{tabular}


Under this investigation, we employed ISCST3 air quality model for the simulation of $\mathrm{PM}_{2.5}$ diffusion. The model as a technique can simulate the pollutants emissions, diffusions, transportation, and pollution sources in specific areas and subsequently evaluate the influence between the source and the receiver. We compared pollutants emissions data from several air quality monitoring stations of three different sampling sites in Kaohsiung City, namely; Dayi Junior High school, Sanmin Home Economics \& Commerce Vocational High School, and Kaohsiung High Administrative Court. To better understand the impacts of various emissions on air quality changes, the selected monitoring sites were separated into three categories: downside, night market, and upside background, which included transportation (road traffic) locations.

This study aims to (1) document the concentrations of air pollutants from a night market in Kaohsiung City, (2) to assess the $\mathrm{PM}_{2.5}$ chemical composition and air quality monitoring from a specific night market and its surrounding areas, and (3) to anticipate the implications of air pollutants emissions from a night market in Kaohsiung City. Our results can be utilized to explain variations in air pollutants at various sites, as well as to guide policymakers in developing mitigation strategies for future air quality improvement in urban areas.

\section{METHODS}

\subsection{Description of Sampling Sites}

The present study has focused on Kaohsiung City as an administrative city government and the largest city in the southern parts of Taiwan. Table 2 abridges the locality and environmental description of the three designated sampling locations. The locations of the three sampling spots are equally shown in Fig. 1 . The upwind site $\left(22^{\circ} 40^{\prime} 28.5^{\prime \prime} \mathrm{N} / 120^{\circ} 17^{\prime} 33.5^{\prime \prime} \mathrm{E}\right)$ is located on the roof of a 4-story building with the height of $12 \mathrm{~m}$ above the ground. Whereas the downwind site $\left(22^{\circ} 39^{\prime} 43.2^{\prime \prime} \mathrm{N} / 120^{\circ} 17^{\prime} 56.7^{\prime \prime} \mathrm{E}\right)$ is situated on the roof of a 3-story building with the height of $10 \mathrm{~m}$ above the ground. The night market sampling site $\left(22^{\circ} 40^{\prime} 01.0^{\prime \prime} \mathrm{N} / 120^{\circ} 18^{\prime} 04.3^{\prime \prime} \mathrm{E}\right)$ is situated on the ground. The three sampling sites of the study areas as indicated in Fig. 1, shows that the topography of the study area is much high in the west-northwest, low in the southeast, and mountainous in the north, which is unfavorable to the transport and dispersion of pollutants. The Dayi Junior High School is located adjacent to mountainous area, and the southwest and northwest sides of the topography mat, whereas the Kaohsiung High Administrative Court is located in a comparatively flat area, which is favorable to the transport and diffusion of pollutants. The meteorological data considered under this investigation comprised of ground monitoring station meteorological data as well as high-altitude meteorological data. Wind direction, wind speed, temperature, and relative humidity were also equally considered as meteorological data.

\subsection{Sampling Intervals and Method}

The fine particulate $\left(\mathrm{PM}_{2.5}\right)$ sampling was conducted into two phases at both locations (upwind and downwind sites) on the $16^{\text {th }}-17^{\text {th }}$ April 2019. Two low-volume ambient air samplers (PQ200 by BGI, Inc., USA) were used to collect two sets of samples (from upwind and downwind sites) at the same time on a $47 \mathrm{~mm}$ quartz fiber filter with a flow rate $16.7 \mathrm{~L} \mathrm{~min}{ }^{-1}$. The first phase was conducted at the night market during the pre-opening period ( 6 a.m. -18 p.m.). The second phase was conducted during the night market opening period (18 p.m. -6 a.m.). Therefore, 4 samples were collected from upwind and downwind sites during the whole sampling period. At the night market sampling site, the traditional pollutions $\left(\mathrm{NO}_{x}, \mathrm{SO}_{2}\right.$ and $\left.\mathrm{CO}\right)$ were collected via air

Table 2. The location of sampling sites and the weather situation.

\begin{tabular}{|c|c|c|c|c|c|c|}
\hline Sampling region & Sampling sites & Abbreviations & Latitude & Longitude & Altitude $(\mathrm{m})$ & Site description \\
\hline Downside & $\begin{array}{l}\text { Kaohsiung High } \\
\text { Administrative Court }\end{array}$ & $\mathrm{KC}$ & $22^{\circ} 39^{\prime} 43.2$ & $120^{\circ} 17^{\prime} 56.7^{\prime \prime}$ & 10 & On the roof \\
\hline $\begin{array}{l}\text { Night market } \\
\text { site }\end{array}$ & $\begin{array}{l}\text { Sanmin Home Economics \& } \\
\text { Commerce Vocational } \\
\text { High School }\end{array}$ & SM & $22^{\circ} 40^{\prime} 01.0^{\prime \prime}$ & $120^{\circ} 18^{\prime} 04.3^{\prime \prime}$ & 1 & On the ground \\
\hline Upside & Dayi Junior High School & DY & $22^{\circ} 40^{\prime} 28.7^{\prime \prime}$ & $120^{\circ} 17^{\prime} 33.5^{\prime \prime}$ & 12 & On the roof \\
\hline
\end{tabular}




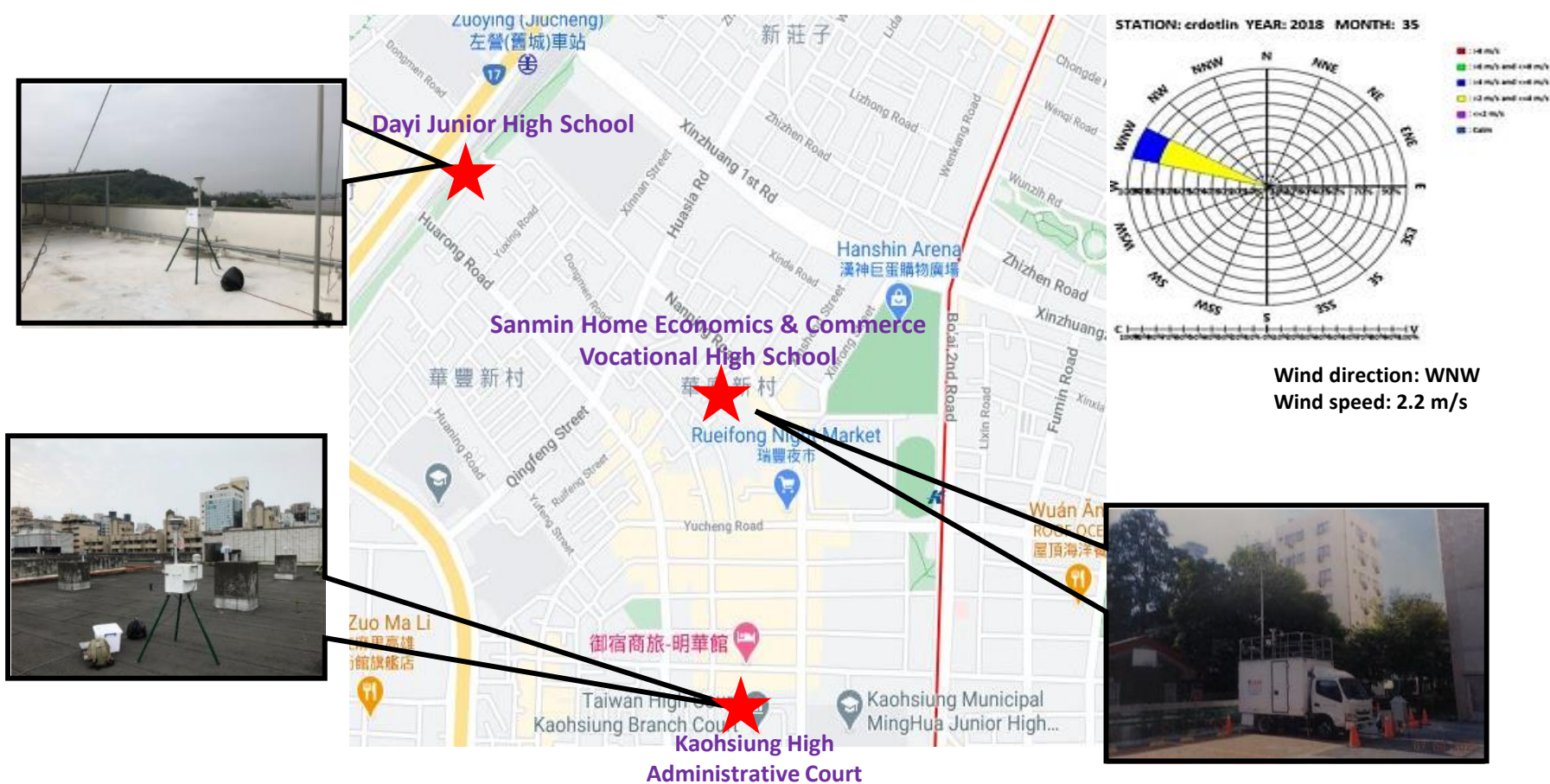

Fig. 1. Schematic diagram of the sampling sites.

quality-monitoring vehicle (from Cheng Shiu Super Micro Mass Research \& Technology Center) on the $16^{\text {th }}-17^{\text {th }}$ April 2019. In the meantime, the $\mathrm{PM}_{2.5}$ sampling was also conducted at this stage.

\subsection{Chemical Compoment Analysis}

After finishing the sampling of $\mathrm{PM}_{2.5}$, the quartz fiber filters were stored for a while in a box with $30-40 \%$ relative humidity to preserve the chemical equilibrium, before being sent to the lab for conditioning, weighing, and further chemical analysis. Prior to the chemical analysis, all of the $\mathrm{PM}_{2.5}$ filters were separated into four portions.

The quarter of quartz fiber filter was digested by microwave digestion method in $15 \mathrm{~mL}$ mixed acidic solution $\left(\mathrm{HNO}_{3}: \mathrm{HCl}=3: 7\right)$ by heating it up to $150^{\circ} \mathrm{C}$ for $0.5 \mathrm{~h}$, and then diluted to $50 \mathrm{~mL}$ with deionized (DI) water for additional investigation of ME. During the absorption procedure, DI water was poured into the remaining solution for multiple times with the intention of removing the digesting solution's acidity. Twelve (12) ME of $\mathrm{PM}_{2.5}$, comprising of $\mathrm{Na}, \mathrm{Ca}, \mathrm{Al}, \mathrm{Fe}, \mathrm{Mg}, \mathrm{Cr}, \mathrm{Mn}$, $\mathrm{Fe}, \mathrm{Cu}, \mathrm{Ba}, \mathrm{Cd}$, and $\mathrm{Pb}$ were examined with the help of Inductively Coupled Plasma Optical Emission Spectroscopy (ICP-OES) (Perkin Elmer, Model Optima, 2000DV).

The carbonaceous species consisting of elemental, organic, and total carbons of $\mathrm{PM}_{2.5}$ had been assessed with the support of elemental analyzer (EA) (Carlo Erba, Model 1108). Before random samplimg, the quartz fiber filters were prepared. The elemental analyzer was functioned through an oxidation procedure at $1020^{\circ} \mathrm{C}$ and a reduction procedure at $500^{\circ} \mathrm{C}$, with constant heating for $15 \mathrm{~min}$. Besides, the organic carbon (OC) component was removed from one eighth of the quartz fiber filters by heating it with hot nitrogen gas $\left(340-350^{\circ} \mathrm{C}\right)$ for 30 minutes before determining the amount of elemental carbon (EC). The remaining eighth of the quartz fiber filter was evaluated without heating, and the carbonaceous species were classified as total carbon (TC) as a result. By subtracting elemental carbon (EC) from total carbon (TC), the amount of organic carbon (OC) was estimated.

\subsection{Simulation Method of $\mathrm{PM}_{2.5}$ Emissions}

The air quality model selected was the Industrial Source Complex Short-Term (ISCST3) type of the ISC (Industrial Source Complex) model series. The model can simulate the emissions, diffusions, transportation, and settlement of pollution sources in the areas to evaluate the influence between the source and the receiver. The ISCST3 model has been modified so that it could be applied to 
the calculation of complex terrains and dry settlements of the gas. It was used for short-term (an hour) to long-term (a year) period as well as for rural and urban simulations. We employed ISCST3 model to simulate the $\mathrm{PM}_{2.5}$ emitted during the night market business period and the data of the regional air quality monitoring stations (Nan-zi, Ren-wu, Zuo-ying, Ai-guo, Zuo-yi and Qian-jin) to simulate the influence of the night market on the concentration of $\mathrm{PM}_{2.5}$ surrounding areas during the night market business period. Finally, the spatial mapping software Surfer 9.0 was used to draw the concentration diffusion diagram as indicated in Fig. 2.

\section{RESULTS AND DISCUSSION}

\subsection{Diffusing Situation of PM 2.5 Simulating by ISCST3 Model}

As presented in Fig. 2, the wind direction is $\mathrm{WN}$; the speed was $2.5 \mathrm{~m} \mathrm{~s}^{-1}$. The simulated diagram of $\mathrm{PM}_{2.5}$ concentration $\left(\mu \mathrm{g} \mathrm{m}^{-3}\right)$ is from the night market sampling data. During the night market opening hours, the $\mathrm{PM}_{2.5}$ concentration from the night market was found to be in the range of 29 to $61 \mu \mathrm{g} \mathrm{m}^{-3}$. The average of concentration was $45 \mu \mathrm{g} \mathrm{m}^{-3}$. During the night market non-opening hours, the $\mathrm{PM}_{2.5}$ concentration data from the night market was found to be in the range of 22 to $38 \mu \mathrm{g} \mathrm{m}^{-3}$. The average of concentration was $25 \mu \mathrm{g} \mathrm{m}^{-3}$ during the sampling time. Several related reports have employed different air pollution diffusion models to simulate and analyze pollutant distributions and consequently offer valuable inputs to air pollution management and decision-making, with ISCST3, AERMOD, and Caline4 being the most prominent techniques. Prakash et al. (2017) evaluated simulation results using ISCST3 and Caline4 to estimate the dissemination of air pollution from point and line sources. They discovered that the ISCST3 model predicted $\mathrm{NO}_{\mathrm{x}}$ and $\mathrm{SO}_{2}$ concentrations well, but Caline4 predicted $\mathrm{PM}_{10}$ concentrations better. ISCST3 and Caline4 were also applied by Karuna et al. (2017) to forecast vehicle emissions as well as to monitor and forecast ambient air quality. They discovered that ISCST3 forecasts were the most accurate in terms of $\mathrm{NO}_{x}$ and $\mathrm{SO}_{2}$ concentrations, while Caline4 overestimated $\mathrm{NO}_{\mathrm{x}}$ levels. Gulia et al. (2014) employed AERMOD, ADMS-Urban, and ISCST3 to estimate air quality at a particular intersection in Delhi, India. They discovered that ISCST3 was better at forecasting CO

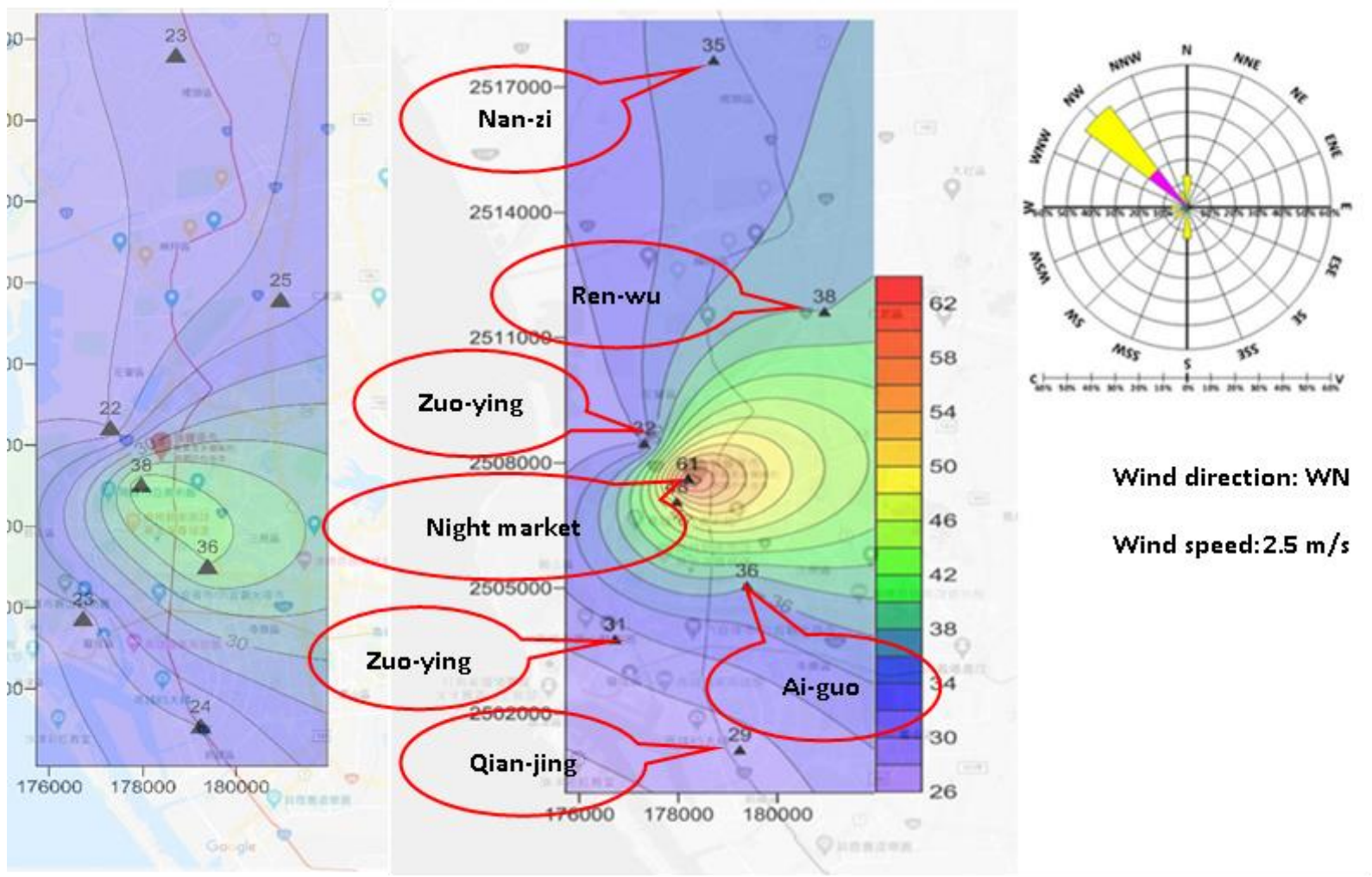

Fig. 2. Simulating $\mathrm{PM}_{2.5}$ diffusion with the ISCST3 model. 
concentrations, while ADMS-Urban was much better at predicting $\mathrm{NO}_{2}$ concentrations, and all three models were accurate at predicting $\mathrm{CO}$ and $\mathrm{PM}_{2.5}$ concentrations. Different modeling methods and/or landscape feature processing could cause variances in model performance. Bajoghli (2019) explored AERMOD and ISCST3 models for the simulations of pollutant dispersion from factory chimneys. They demonstrated that AERMOD was exceptional as compares to ISCST3, although ISCST3 calls for less input data, which was advantageous for small-area investigations. The present investigation also demonstrates that ISCST3 is an excellent model for simulating air pollutants from the night market, particularly for the assessment of $\mathrm{PM}_{2.5}$ chemical composition and air quality monitoring.

\subsection{Differences in Metallic Elements Concentrations in $\mathbf{P M}_{2.5}$}

Various ME concentrations in the $\mathrm{PM}_{2.5}$ under this study are displayed in the Table 3. The $\mathrm{PM}_{2.5}$ concentration from the night market site during the opening period was recorded as follow: $\mathrm{Na}$ had the maximum concentration of $4590 \mathrm{ng} \mathrm{m}^{-3}$, while Fe was recorded with the second highest concentration of $1820 \mathrm{ng} \mathrm{m}^{-3}$, and Al with the concentration of $1600 \mathrm{ng} \mathrm{m}^{-3}$. While during the pre-opening period, the $\mathrm{PM}_{2.5}$ concentration was recorded as follow: Fe had the highest concentration of $1340 \mathrm{ng} \mathrm{m}^{-3}$, followed by Al the second highest concentration of $1100 \mathrm{ng} \mathrm{m}^{-3}$, and $\mathrm{Na}$ with the concentration $928 \mathrm{ng} \mathrm{m}^{-3}$. In the non-opening period, the $\mathrm{PM}_{2.5}$ concentration was recorded as following: Na had the highest concentration of $3570 \mathrm{ng} \mathrm{m}^{-3}$, followed by Fe with the second highest concentration of $1430 \mathrm{ng} \mathrm{m}^{-3}, \mathrm{Ca}$ and Al with a similar concentration of $806 \mathrm{ng} \mathrm{m}^{-3}$. According to our sampling results, $\mathrm{Na}$ could have probably originated from oil-based cooking activities due to the use of large amount of salt when the night market opening (Zhang et al., 2017; Zhao et al., 2019). The majority of Fe, Al and Ca could have probably been derived from emission of vehicles when the night market was opened (Lin et al., 2020). Our findings are in consistent with those of Ojekunle et al. (2018), who found that in a study conducted in Nigeria, ME for example $\mathrm{Cd}, \mathrm{Cr}$, $\mathrm{Ca}, \mathrm{Cu}$, and $\mathrm{Zn}$ all had greater amounts in $\mathrm{PM}_{2.5}$ than the WHO criterion. Almost one-third of the $\mathrm{Zn}$ in air dust was attributed to pollutant emissions from vehicles such as diesel automobiles in a research done in Great Britain by Harrison et al. (2012). Comparatively, Liu et al. (2018) conducted a similar study in Beijing, China, on the importance of emission reduction for $\mathrm{PM}_{2.5}$-bound $\mathrm{ME}$ in various seasons. They discovered that $\mathrm{Ca}$ was one of the ME noted in yearly trends in higher emission levels, with resuspended dust modeling the highest bulk contribution to $\mathrm{PM}_{2.5}$-bound $\mathrm{ME}$.

In a single ICP investigation, the source of metallic species and their consequences on human well-being at absorptions of up to 30 ambient $\mathrm{ME}$ may be determined concomitantly with a \pm 55 ppm precision (Watson, 2010). $\mathrm{Mg}, \mathrm{Na}, \mathrm{Cr}, \mathrm{Mn}, \mathrm{Fe}, \mathrm{Cu}, \mathrm{Al}, \mathrm{Ba}, \mathrm{Cd}, \mathrm{Pb}$, and $\mathrm{Ca}$ were among the atmospheric ME discovered in this research. These ME have been discovered to have $a$ significant impact on human health. In their investigation of MEs pollution in Asia from 2000 to 2007, Fang et al. (2010) discovered that exposure to particular MEs can provide a variety of dangers to humans. Excessive exposure to Fe, for example, can cause pneumoconiosis, whereas excessive exposure to $\mathrm{Zn}$ can cause heart disease and hypertension. Notably, they also discovered that $\mathrm{Cr}(\mathrm{VI})$ is carcinogenic and can induce asthma and liver damage, among other things (Banu et al., 2017; Oruko et al., 2020).

In many instances, $\mathrm{Cr}$ species have the ability to enter the eukaryotic system and initiate imprudent interactions with intracellular reductants, such as ascorbate and glutathione, resulting

Table 3. Metallic element concentrations in the $\mathrm{PM}_{2.5}\left(\mathrm{ng} \mathrm{m}^{-3}\right)$.

\begin{tabular}{|c|c|c|c|c|c|c|c|c|c|c|c|c|}
\hline \multirow{2}{*}{ Sampling location } & \multirow{2}{*}{ Sampling interval } & \multicolumn{11}{|c|}{ Metallic elements } \\
\hline & & $\mathrm{Na}$ & $\mathrm{Ca}$ & $\mathrm{Al}$ & $\mathrm{Fe}$ & $\mathrm{Mg}$ & $\mathrm{Cr}$ & $\mathrm{Mn}$ & $\mathrm{Cu}$ & $\mathrm{Ba}$ & $\mathrm{Cd}$ & $\mathrm{Pb}$ \\
\hline \multirow[t]{2}{*}{ Upwind } & (06:00-18:00) & 859 & 1310 & 870 & 844 & 933 & 459 & 502 & 642 & 483 & 741 & 1310 \\
\hline & $(18: 00-06: 00)$ & 769 & 666 & 769 & 759 & 769 & 459 & 502 & 642 & 478 & 652 & 666 \\
\hline \multirow[t]{2}{*}{ Downwind } & $(06: 00-18: 00)$ & 875 & 1190 & 947 & 1120 & 773 & 511 & 497 & 647 & 488 & 595 & 1190 \\
\hline & $(18: 00-06: 00)$ & 2860 & 825 & 1020 & 1310 & 853 & 502 & 502 & 647 & 478 & 600 & 825 \\
\hline Pre-open hours & (14:00-18:00) & 928 & 922 & 1100 & 1340 & 853 & 698 & 492 & 745 & 947 & 488 & 922 \\
\hline Open hours & $(18: 00-02: 00)$ & 4590 & 1060 & 1600 & 1820 & 817 & 600 & 492 & 733 & 486 & 601 & 1060 \\
\hline Non-open hours & $(02: 00-06: 00)$ & 3570 & 806 & 806 & 1430 & 778 & 563 & 502 & 736 & 483 & 600 & 806 \\
\hline
\end{tabular}


in $\mathrm{Cr}(\mathrm{V})$ and/or $\mathrm{Cr}(\mathrm{IV})$ intermediates, free radicals, and $\mathrm{Cr}(\mathrm{III})$ end-products (Oruko et al., 2020). The cytoplasmic intermediates are oxidized to $\mathrm{Cr}(\mathrm{VI})$, which rapidly interacts with DNA protein multiplexes and changes their normal biological functions (Sun et al. , 2019) in addition to damaging their DNA that has genotoxic and mutagenic implications (Oruko et al., 2020). Furthermore, $\mathrm{Cr}(\mathrm{VI})$ species can amass in the placenta and harm the growth of the fetus, resulting in birth abnormalities and a decline in reproductive health (Banu et al., 2017).

Additionally, Cu may cause various health issues such as lung cancer, interstitial fibrosis, and pulmonary granuloma, whilst $\mathrm{Cd}$ and $\mathrm{Pb}$ exposure can result in blood poisoning, anemia, and itaiitai illness. These MEs might find their way into coastal waterways and estuaries, posing a serious threat to aquatic animals' lives and activities, as well as posing a significant risk of death. As a result, MEs buildup in marine ecosystems has become a major global issue. Contamination with MEs could have disastrous consequences for the environment's ecological balance, as well as a severe impact on aquatic life diversity (Oruko et al., 2020). Fish are among the species of animals that are unable to escape the detrimental impacts of these ME contaminants (Banu et al., 2017). Wang et al. (2019) investigated the health risks of $\mathrm{PM}_{2.5}$ in student dormitories at a Chinese university and discovered that MEs in the dormitory were made up of a mix of emissions from coal burning and industrial activities. Wei et al. (2019) highlighted that exposure to pollutant emissions could lead to the occurrence of myopia. They stressed out that continuous exposure to $\mathrm{PM}_{2.5}$ and $\mathrm{NO}_{\mathrm{x}}$ can worsen ocular surface pain and, later, retinal inflammation, raising the likelihood of myopia development.

\subsection{Carbonaceous Species of $\mathrm{PM}_{2.5}$}

Atmospheric carbonaceous compounds in the aerosol particles entail mostly of EC and OC. Engine lubricating fluid, unburned fuel, and modest amounts of incomplete combustion and pyrolysis products were all found in the organic material (Chen et al., 2019). EC is the product of incomplete combustion from the vehicles fuel, and residential coal burning. While the biomass burning was thought to produce more OC (Pani et al., 2019). Our results in Table 4, showed the concentration of organic carbons was in the range of 0.17 to $2.70 \mu \mathrm{g} \mathrm{m}^{-3}$, the highest and lowest interval of concentration were 2.70 and $0.46 \mu \mathrm{g} \mathrm{m}^{-3}$, respectively. The EC concentration was in the range of 2.52 to $6.53 \mu \mathrm{g} \mathrm{m}^{-3}$, the highest and lowest interval of concentration were 6.53 and $2.52 \mu \mathrm{g} \mathrm{m}^{-3}$, respectively. We found that at the upwind site (06:00-18:00) the OC/EC ratio was 1.07. The other sampling period (18:00-06:00), the OC/EC ratios was 0.992. According to the study by Watson et al. (2010), OC/EC ratios were in the range of 0.7-2.4 are mostly from vehicles exhausts. Furthermore, the upwind sampling site was located near the main traffic area. Therefore, the air quality of upwind sampling site was seriously impacted by traffic conditions. On the other hand, at the downwind sampling site (06:00-18:00) the OC/EC ratio was observed to be 0.081 . The other sampling period (18:00-06:00), the OC/EC ratios was 0.026 and the results showed that the elemental carbons was the primary contaminant. Notwithstanding that, most of the TC species are generally ascribed to metallic species and other $\mathrm{PM}_{2.5}$ components and additional $\mathrm{PM}_{2.5}$ components for instance, the concentrations of the major common three main inorganic ions in $\mathrm{PM}_{2.5}, \mathrm{SO}_{4}{ }^{2-}$ (sulfate), $\mathrm{NO}_{3}{ }^{-}$(nitrate), and $\mathrm{NH}_{4}{ }^{+}$, (ammonium) (Jiang et al., 2019).

\subsection{Traditional Pollutants}

As presented in Fig. 3, the carbon monoxide (CO) 24-hour average concentration was observed in several air quality monitoring stations (Zuo-ying, Ai-guo, Qian-jin and Feng-shan) and night market sampling site. According to the $\mathrm{CO}$ average concentration data of the air quality monitoring

Table 4. The concentration of the carbonaceous species $\left(\mu \mathrm{g} \mathrm{m}^{-3}\right)$.

\begin{tabular}{|c|c|c|c|c|c|}
\hline Location & Sample intervals & $\mathrm{TC}\left(\mu \mathrm{g} \mathrm{m}^{-3}\right)$ & $\mathrm{EC}\left(\mu \mathrm{g} \mathrm{m}^{-3}\right)$ & $\mathrm{OC}\left(\mu \mathrm{g} \mathrm{m}^{-3}\right)$ & OC/EC $\left(\mu \mathrm{g} \mathrm{m}^{-3}\right)$ \\
\hline \multirow[t]{2}{*}{ Upwind } & $(06: 00-18: 00)$ & 5.22 & 2.52 & 2.70 & 1.07 \\
\hline & $(18: 00-06: 00)$ & 5.04 & 2.53 & 2.51 & 0.992 \\
\hline \multirow[t]{2}{*}{ Downwind } & (06:00-18:00) & 6.13 & 5.67 & 0.46 & 0.081 \\
\hline & $(18: 00-06: 00)$ & 6.52 & 6.53 & 0.17 & 0.026 \\
\hline Pre-open hours & $(14: 00-18: 00)$ & 5.40 & 4.72 & 0.68 & 0.144 \\
\hline
\end{tabular}




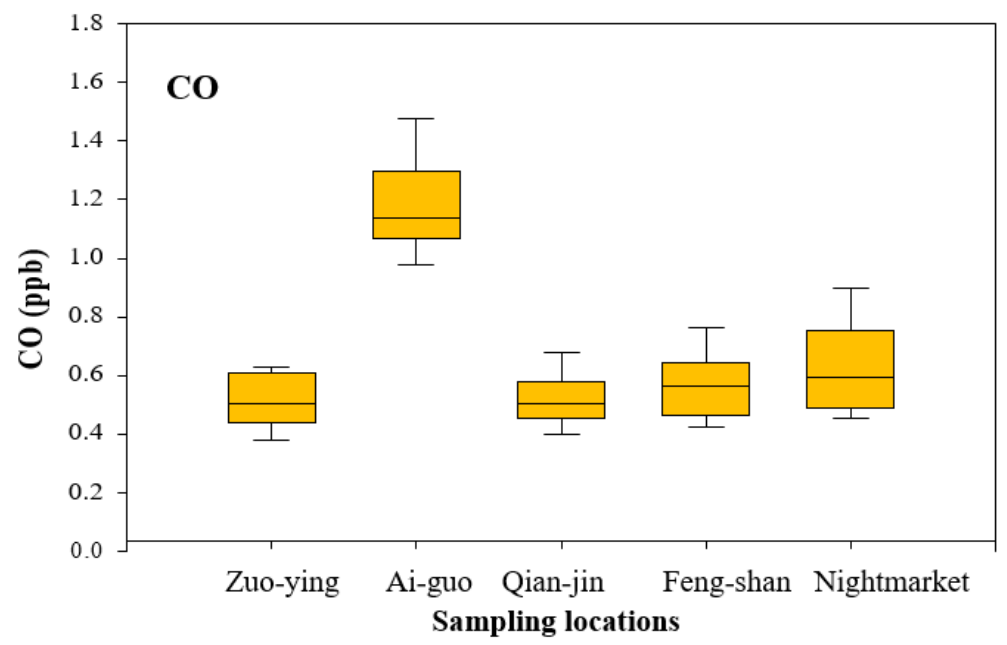

Fig. 3. Carbon monoxide (CO) 24 hours average concentration.

stations, the maximum average concentration is $0.76 \mathrm{ppb}$, with the minimum average concentration of $0.71 \mathrm{ppb}$ and daily average concentration is $0.51 \mathrm{ppb}$ at the Zuo-ying air quality monitoring station. The maximum average concentration was $1.62 \mathrm{ppb}$, the minimum average concentration is $0.95 \mathrm{ppb}$ and the daily average concentration was $1.18 \mathrm{ppb}$ at the Ai-guo station. At Qian-jin station, a maximum average concentration of $0.71 \mathrm{ppb}$ was recorded, while the minimum average concentration of $0.33 \mathrm{ppb}$ and a daily average concentration of $0.52 \mathrm{ppb}$ was also reported. Furthermore, a maximum average concentration of $0.85 \mathrm{ppb}$, a minimum average concentration of $0.42 \mathrm{ppb}$ along with a daily average concentration of $0.57 \mathrm{ppb}$ was reported at Feng-shan station. Yet a maximum average concentration of $0.92 \mathrm{ppb}$, with a minimum average concentration of $0.39 \mathrm{ppb}$ and the daily average concentration of $0.63 \mathrm{ppb}$ were observed at night market sampling site. By evaluating the $\mathrm{CO}$ concentration data, we found out that the concentration at the Ai-guo station was much higher than others air monitoring stations. The Ai-guo station have many incomplete combustion activities, particularly from the surrounding temples.

As indicated in Fig. 4, the nitrogen oxides $\left(\mathrm{NO}_{\mathrm{x}}\right)$ 24-hour average concentration in several air quality monitoring stations and night market sampling site. According to the $\mathrm{NO}_{\mathrm{x}}$ concentration results of the air quality monitoring stations, the maximum average concentration was $29 \mathrm{ppb}$, with a minimum average concentration of $4.3 \mathrm{ppb}$ and a daily average concentration data of $17 \mathrm{ppb}$ at Zuo-ying station. However, a maximum average concentration of $38 \mathrm{ppb}$, while the

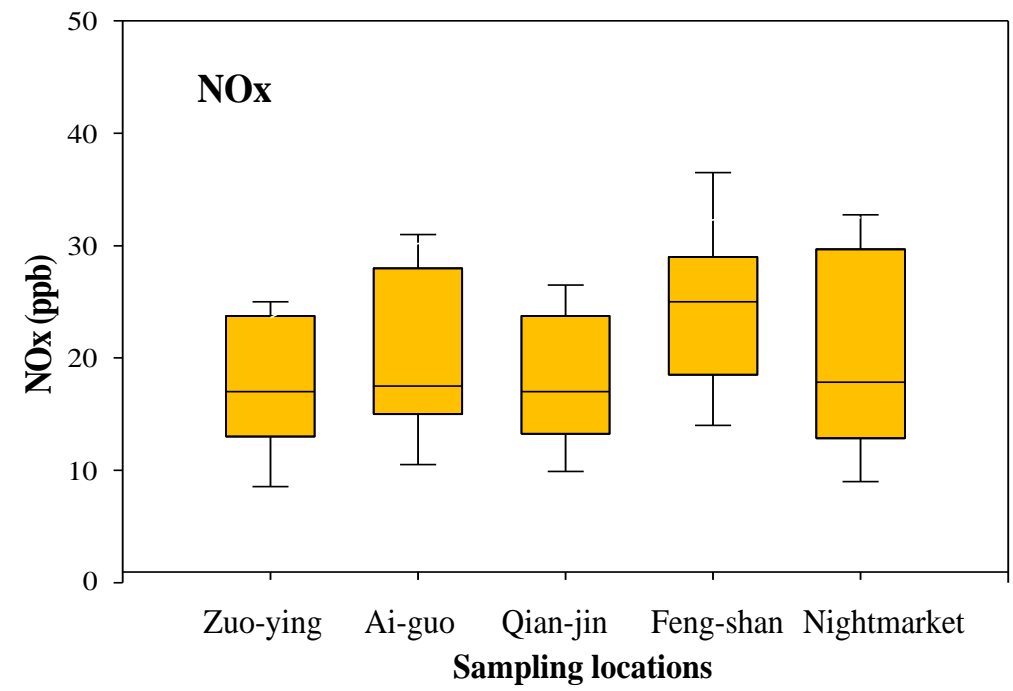

Fig. 4. Nitrogen oxides $\left(\mathrm{NO}_{\mathrm{x}}\right) 24$ hours average concentration. 
minimum average concentration of $9.1 \mathrm{ppb}$ and the daily average concentration of $20 \mathrm{ppb}$ were reported at Ai-guo station. At Qian-jin station, a maximum average concentration of $27 \mathrm{ppb}$, with a minimum average concentration of $7.4 \mathrm{ppb}$ and a daily average concentration of $17 \mathrm{ppb}$ was equally reported. On the other hand, a maximum average concentration of $39 \mathrm{ppb}$, with the minimum average concentration of $11 \mathrm{ppb}$ and a daily average concentration of $24 \mathrm{ppb}$ was account for at Feng-shan station. Nevertheless, a maximum average concentration of $34 \mathrm{ppb}$, with a minimum average concentration of $7.1 \mathrm{ppb}$ and a daily average concentration of $20 \mathrm{ppb}$ was recorded at the night market sampling site. Upon evaluating the $\mathrm{NO}_{\mathrm{x}}$ concentration results, we found out that the concentration at the Ai-guo station was much higher than others air monitoring stations. It was therefore discovered that the location of Ai-guo station was at the main traffic road, thus the vehicles influenced the concentration. Based on the past research, in many urban areas, one the of the most important sources of air pollution is road traffic with major contribution to $\mathrm{NO}_{\mathrm{x}}$ emissions (Santoso et al., 2021). For instance, in the UK, $23 \%$ of total $\mathrm{NO}_{\mathrm{x}}$ was generated by cars and light duty vehicles (LDVs) (Wakeling et al., 2016).

Fig. 5 depicts the sulfur dioxide $\left(\mathrm{SO}_{2}\right)$ 24-hour average concentration in several air quality monitoring stations and night market sampling site. According to the $\mathrm{SO}_{2}$ concentration results of the air quality monitoring stations, the maximum average concentration was $7.0 \mathrm{ppb}$, with the minimum average concentration of $1.8 \mathrm{ppb}$ and the daily average concentration data of $2.9 \mathrm{ppb}$ at the Zuo-ying station. The maximum average concentration is $4.1 \mathrm{ppb}$, whereas the minimum average concentration was $2.1 \mathrm{ppb}$ and the daily average concentration was observed to be $2.1 \mathrm{ppb}$ at the Ai-guo station. A maximum average concentration of $4.3 \mathrm{ppb}$ and a daily average concentration of $2.6 \mathrm{ppb}$ was reported at the Qian-jin station. The Feng-shan station had a maximum average concentration of $6.5 \mathrm{ppb}$, with a minimum average concentration of $2.1 \mathrm{ppb}$ and a daily average concentration of $3.6 \mathrm{ppb}$. In addition, the night market sampling site had a maximum average concentration of $3.4 \mathrm{ppb}$, with a minimum average concentration of $1.7 \mathrm{ppb}$ and a daily average concentration of $1.7 \mathrm{ppb}$. Based on the analysis of the SOx concentration results, we found out that the concentration at the Feng-shan station was much higher than other stations. According to the IEA (2016), almost all sulfur oxides originate from the production of energy. Besides, the location of Feng-shan station is in the proximity of Dafa industrial park. Thus, it can be concluded that the industrial park is the main resource of $\mathrm{SO}_{2}$ concentration at the Fengshan station.

Furthermore, petrochemical industrial zones have been reported as another major causes of pollution the environment in a number of countries, with dangerous air pollutants discharge accounting for a significant portion of that damage (Lin et al., 2021). For instance, $\mathrm{CO}, \mathrm{SO}_{2}, \mathrm{NO}_{2}$, ozone, suspended particulate matter, and other air pollutants in Malaysian cities, are mostly attributable to industrial emissions or combustion (Dahari et al., 2019; Khan et al., 2018; Sulong et al., 2017). Elsewhere, industrial pollution has been reported to be frequent in Spanish cities within $5 \mathrm{~km}$ of industrial zones, with elevated benzene, dioxin, and PCB concentrations. As a result,

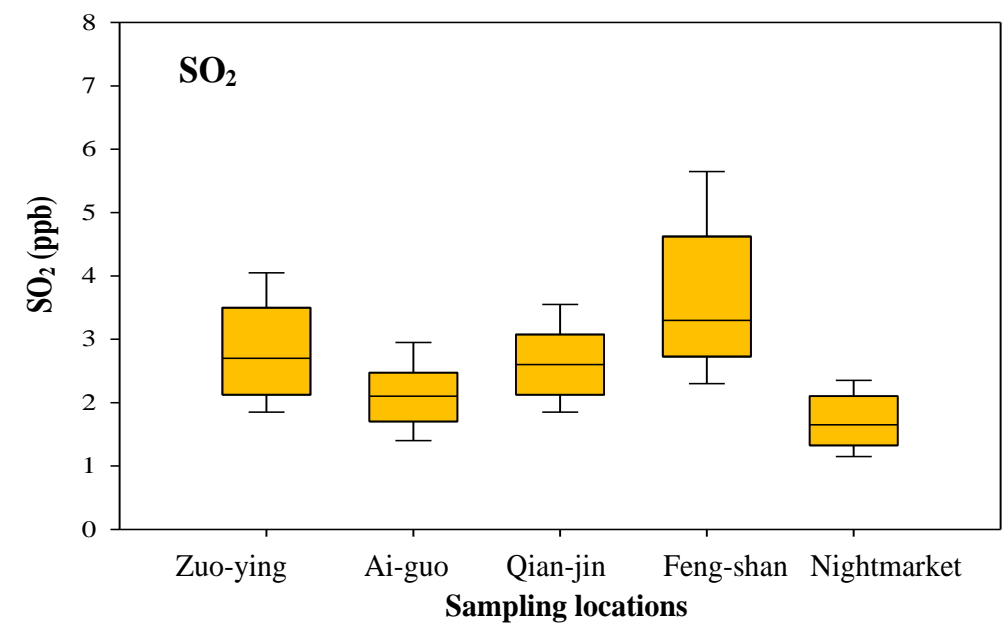

Fig. 5. Sulfur dioxide $\left(\mathrm{SO}_{2}\right) 24$ hours average concentration. 
cancer mortality is up to $17 \%$ higher in exposed areas than in non-exposed ones (FernándezNavarro et al., 2017). This study investigated the chemical composition of $\mathrm{PM}_{2.5}$ and air quality monitoring while taking into consideration the implications of air pollutants emissions from a night market in Kaohsiung City, Taiwan. Few public schools and government institutions were observed to be likely affected by air pollutants emissions from the night market, and the residents in the vicinity of the affected areas are more likely to be exposed to higher air pollutants and health risks. The simulated results under this investigation are compatible with Taiwan's overall air pollution season (winter and spring). The ultimate underlying reason is that the major predominant wind of the northeast monsoon and the cold high pressure system that travels from China passing across Taiwan in the winter and spring (Lin et al., 2021). As a result of the mountains, half of Taiwan is usually affected by weak synoptical weather, which is linked to the lowest wind speeds and greatest $\mathrm{PM}_{2.5}$ concentrations (Lin et al., 2021; Hsu and Cheng, 2019). In addition, pollution is likely to build up in the upwind areas, especially in central and southwestern Taiwan (Cheng and Hsu, 2019; Hsu and Cheng, 2019). Also, the northeast monsoon inclines to transport pollution from west China into this region (Lin et al., 2021).

\section{LIMITATIONS OF THE STUDY}

There are a few drawbacks to this study. Due to limited resources, the present investigation had only considered one night market as a sampling site, despite the fact that there are many night markets in Kaohsiung City and Taiwan in particular. In such circumstances, this particular night market located in a densely populated was subsequently considered for the present investigating.

In air quality monitoring data analysis, we assumed that the results could be generalized or replicated to other various night markets in Kaohsiung City, taking into consideration that all night markets have the same operational hours, i.e., pre-opening hours, opening hours and nonopening hours. The sampling intervals used in the study are based on the actual operational hours of the night markets in Kaohsiung City.

The results projected by this analysis are based on various meteorological parameters and other industrial activities in the proximity of the studied areas. The actual implications arising from air quality monitoring stations could vary from the various night markets, depending on the location of such night market. Due to the current restrictions on different business and economic activities since the outbreak of COVID-19, the concentration of chemical composition in the PM 2.5 could be much higher on normal business operations. In such a case, the current analysis and results will act as a base to formulate guidelines on the operations of night markets in Taiwan. This will help to drastically minimize the impacts of air pollutants emissions from the night markets in Kaohsiung City and in other places in Taiwan.

COVID-19 has serious effect on the air quality across the globe, particularly under the emergency lockdown. While the world is concerned about effective regulations for air pollutants emissions mitigation measures, this emergency lockdown has turned into an important step in the environment recovery, as emissions sources (such as night markets) were controlled by this swift move. As a result, the lockdown measure has resulted in a considerable reduction in air pollution contamination, allowing academics and governments to better understand the background and future strategies for pollution control (Albayati et al., 2021). According to Kotnala et al. (2020), the air pollution level in the New Delhi (India) areas has declined more than in comparison to other areas as a result of the lockdown. Their results were based on data acquired from the Central Pollution Control Board (CPCB) in New Delhi's 12 air pollution monitoring sites. Particulate matter with diameters of 2.5 and $10 \mu \mathrm{g}\left(\mathrm{PM}_{2.5}\right.$ and $\left.\mathrm{PM}_{10}\right)$ had drastically declined by $200 \%$. In addition to this, nitrous oxides ( $\mathrm{NO}_{\mathrm{x}}$ ) concentrations in CRRI-Mathura Road, Delhi, was observed to have been reduced from $342 \mathrm{ppb}$ on January 12th, 2020 to $24 \mathrm{ppb}$ on March $30^{\text {th }}, 2020, \mathrm{a}$ reduction of almost 1400\% (Kotnala et al., 2020). In an attempt to restrict the number of illnesses and prevent the spread of COVID-19 in communities, governments around the world, including Taiwan, have imposed quarantine and limited communication. With these restrictions (lockdowns) people were compelled to stay at home for longer periods of time, resulting in increasing indoor air pollution. According to the World Health Organization (WHO), 3.8 million people died in 2016 
as a result of breathing contaminated indoor air. Certainly, smoking, cooking over an open flame, inadequate ventilation, and the use of chemicals, particularly volatile compounds, all contribute to poor indoor air quality (Hadi et al., 2020b; Alalwan and Alminshid, 2020; Alminshid et al., 2021). As a result of the quarantine, people are forced to stay indoors for an extended period of time, which increases the risk of significant diseases such as lower respiratory acute infections, chronic obstructive pulmonary disease, cardiovascular disease, lung cancer, and asthma (Ansari and Ahmadi Yousefabad, 2020).

Thus, the present study is one of the very few studies to assess the implications of air pollutants emissions from a night market in Kaohsiung City, Taiwan. This research work will be a valuable guiding tool for policymakers working on the implementation of the new emission standards, particularly $\mathrm{PM}_{2.5}$ and traditional pollutants.

\section{CONCLUSIONS}

This study provides some new insights into the assessment of $\mathrm{PM}_{2.5}$ chemical composition and air quality monitoring. The findings of this study contribute evidence about the implications of air pollutants emissions from a particular night market. According to our results, the $\mathrm{PM}_{2.5}$ concentrations during the night market opening hours was about 1.6 times than the concentrations observed during pre-opening intervals. It is an evident that the $\mathrm{PM}_{2.5}$ concentration influenced by night market activities. Concerning the concentration of $\mathrm{ME}$ in $\mathrm{PM}_{2.5}$, the results demonstrated that the concentrations of ( $\mathrm{Fe}, \mathrm{Al}$ and $\mathrm{Ca}$ ) can be attributed to the night market business activities. On the carbonaceous species, our results demonstrated that the element carbon and the organic carbon were influenced by traffic situations, which happened during the night market opening hours. The present study employed an Industrial Source Complex Short-Term (ISCST3) air quality model for the simulation of $\mathrm{PM}_{2.5}$ diffusion in order to identify the hypothetically risk $\mathrm{PM}_{2.5}$ areas as a reflection of air quality monitoring in the vicinity of night markets. Understanding and quantifying $\mathrm{PM}_{2.5}$ chemical composition could help us to quickly identify key risky areas in the proximity of night markets and to what extent significant night market activities and operational hours may otherwise cause changes in air pollutants emissions and contamination levels. Overall, this study revealed that the night markets activities could contribute to poor air quality. In future research, we suggest that, in addition to schools and government agencies, other public avenues that can be considered as key risky areas in the proximity of night markets should be included in the investigation of this nature for enhanced risk prevention and mitigation.

\section{ACKNOWLEDGMENTS}

The authors would like to thank the National Sun Yat-sen University (NSYSU) and Kaohsiung Medical University (KMU), for financially supporting this research under the NSYSU-KMU Joint Research Project (NSYSUKMU 108-1004).

\section{REFERENCES}

Alalwan, H., Alminshid, A. (2020). An in-situ DRIFTS study of acetone adsorption mechanism on $\mathrm{TiO}_{2}$ nanoparticles. Spectrochim. Acta, Part A 229, 117990. https://doi.org/10.1016/j.saa.2019. 117990

Alminshid, A.H., Abbas, M.N., Alalwan, H.A., Sultan, A.J., Kadhom, M.A. (2021). Aldol condensation reaction of acetone on $\mathrm{MgO}$ nanoparticles surface: An in-situ drift investigation. Mol. Catal. 501, 111333. https://doi.org/10.1016/j.mcat.2020.111333

Ansari, M., Ahmadi Yousefabad, S. (2020). Potential threats of COVID-19 on quarantined families. Publ. Health 183, 1. https://doi.org/10.1016/j.puhe.2020.04.014

Asadi, M., Asadollahfardi, G., Fakhraee, H., Mirmohammadi, M. (2017). The comparison of Lagrangian and Gaussian models in predicting of air pollution emission using experimental study, a case study: Ammonia emission. Environ. Model. Assess. 22, 27-36. https://doi.org/10. 1007/s10666-016-9512-8 
Bajoghli, M. (2019). Comparison of application of AERMOD and ISCST3 models for simulating the dispersion of emitted pollutant from the stack of an industrial plant in different time scales. Arch. Occup. Health 3, 245-251. https://doi.org/10.18502/aoh.v3i1.342

Banu, S.K., Stanley, J.A., Sivakumar, K.K., Arosh, J.A., Taylor, R.J., Burghardt, R.C. (2017). Chromium VI - Induced developmental toxicity of placenta is mediated through spatiotemporal dysregulation of cell survival and apoptotic proteins. Reprod. Toxicol. 68, 171-190. https://doi.org/10.1016/j.reprotox.2016.07.006

Binkowski, F.S., Roselle, S.J. (2003). Models-3 Community Multiscale Air Quality (CMAQ) model aerosol component 1. Model description. J. Geophys. Res. 108, 4183. https://doi.org/10.1029/ 2001JD001409

Butland, B.K., Samoli, E., Atkinson, R.W., Barratt, B., Beevers, S.D., Kitwiroon, N., Katsouyanni, K. (2020). Comparing the performance of air pollution models for nitrogen dioxide and ozone in the context of a multilevel epidemiological analysis. Environ. Epidemiol. 4, e0933. https://doi.org/10.1097/EE9.0000000000000093

Canha, N., Lage, J., Coutinho, J.T., Alves, C., Almeida, S.M. (2019). Comparison of indoor air quality during sleep in smokers and nonsmokers' bedrooms: A preliminary study. Environ. Pollut. 249, 248-256. https://doi.org/10.1016/j.envpol.2019.03.021

Carugno, M., Dentali, F., Mathieu, G., Fontanella, A., Mariani, J., Bordini, L., Milani, G.P., Consonni, D., Bonzini, M., Bollati, V., Pesatori, A.C. (2018). $\mathrm{PM}_{10}$ exposure is associated with increased hospitalizations for respiratory syncytial virus bronchiolitis among infants in Lombardy, Italy. Environ. Res. 166, 452-457. https://doi.org/10.1016/j.envres.2018.06.016

Chen, Q.X., Huang, C.L., Yuan, Y., Tan, H.P. (2020). Influence of COVID-19 event on air quality and their association in mainland China. Aerosol Air Qual. Res. 20, 1541-1551. https://doi.org/10. 4209/aaqr.2020.05.0224

Chen, S., Cui, K., Zhu, J., Zhao, Y., Wang, L.C., Mutuku, J.K. (2019). Effect of exhaust gas recirculation rate on the emissions of persistent organic pollutants from a diesel engine. Aerosol Air Qual. Res. 19, 812-819. https://doi.org/10.4209/aaqr.2019.01.0047

Chen, S.C., You, Z.S., Chang, I.Y. (2014). Probabilistic risk assessment of consumer exposure to particle-bound PAHs at a Taiwanese night market. Int. J. Environ. Res. 8, 643-652. https://doi.org/10.22059/ijer.2014.759

Cui, M., Chen, Y., Feng, Y., Li, C., Zheng, J., Tian, C., Yan, C., Zheng, M. (2017). Measurement of PM and its chemical composition in real-world emissions from non-road and on-road diesel vehicles. Atmos. Chem. Phys. 17, 6779-6795. https://doi.org/10.5194/acp-17-6779-2017

Dahari, N., Muda, K., Khan, M.F., Latif, M.T., Hussein, N., Dominick, D. (2021). Chemical characterization and source apportionment of $\mathrm{PM}_{2.5}$ near semi-urban residential-industrial areas. Expo. Health. https://doi.org/10.1007/s12403-021-00425-5

Dai, Q., Bi, X., Liu, B., Li, L., Ding, J., Song, W., Bi, S., Schulze, B.C., Song, C., Wu, J., Zhang, Y., Feng, Y., Hopke, P.K. (2018). Chemical nature of $\mathrm{PM}_{2.5}$ and $\mathrm{PM}_{10}$ in Xi'an, China: Insights into primary emissions and secondary particle formation. Environ. Pollut. 240, 155-166. https://doi.org/10. 1016/j.envpol.2018.04.111

Fang, G.C., Huang, Y.L., Huang, J.L. (2010). Study of atmospheric metallic elements pollution in Asia during 2000-2007. J. Hazard. Mater. 180, 115-121. https://doi.org/10.1016/j.jhazmat.201 0.03.120

Fernández-Navarro, P., García-Pérez, J., Ramis, R., Boldo, E., López-Abente, G. (2017). Industrial pollution and cancer in Spain: an important public health issue. Environ. Res. 159, 555-563. https://doi.org/10.1016/j.envres.2017.08.049

Gondalia, R., Baldassari, A., Holliday, K.M., Justice, A.E., Méndez-Giráldez, R., Stewart, J.D., Liao, D., Yanosky, J.D., Brennan, K.J.M., Engel, S.M., Jordahl, K.M., Kennedy, E., Ward-Caviness, C.K., Wolf, K., Waldenberger, M., Cyrys, J., Peters, A., Bhatti, P., Horvath, S., Assimes, T.L., et al. (2019). Methylome-wide association study provides evidence of particulate matter air pollution-associated DNA methylation. Environ. Int. 132, 104723. https://doi.org/10.1016/j.en vint.2019.03.071

Gulia, S., Nagendra, S.S., Khare, M. (2014). Performance evaluation of ISCST3, ADMS-Urban and AERMOD for urban air quality management in a mega city of India. Int. J. Sustain. Dev. 9, 778793. https://doi.org/10.2495/SDP-V9-N6-778-793

Hadi, A.G., Kadhom, M., Hairunisa, N., Yousif, E., Mohammed, S.A. (2020b). A review on COVID- 
19: Origin, spread, symptoms, treatment, and prevention. Biointerface Res. Appl. Chem. 10, 7234-7242. https://doi.org/covidwho-633774

Hanna, S.R., Egan, B.A., Purdum, J., Wagler, J., (2001). Evaluation of the ADMS, AERMOD, and ISC3 dispersion models with the OPTEX, Duke Forest, Kincaid, Indianapolis and Lovett field datasets. Int. J. Environ. 16, 301-314. https://doi.org/10.1504/IJEP.2001.000626

Harrison, R.M., Jones, A.M., Gietl, J., Yin, J., Green, D. (2012). Estimation of the contribution of brake dust, tire wear and resuspension to non-exhaust traffic particles derived from atmospheric measurements. Environ. Sci. Technol. 46, 6523-6529. https://doi.org/10.1021/es 300894r

Hashim, B.M., Al-Naseri, S.K., Al-Maliki, A., Al-Ansari, N. (2021). Impact of COVID-19 lockdown on $\mathrm{NO}_{2}, \mathrm{O}_{3}, \mathrm{PM}_{2.5}$ and $\mathrm{PM}_{10}$ concentrations and assessing air quality changes in Baghdad, Iraq. Sci. Total Environ. 754, 141978. https://doi.org/10.1016/j.scitotenv.2020.141978

Hu, J., Pan, Y., He, Y., Chi, X., Zhang, Q., Song, T., Shen, W. (2021). Changes in air pollutants during the COVID-19 lockdown in Beijing: Insights from a machine-learning technique and implications for future control policy. Atmos. Ocean. Sci. Lett. 14, 100060. https://doi.org/10.1016/j.aosl.2 021.100060

Huang, K.L., Liu, S.Y., Chou, C.C., Lee, Y.H., Cheng, T.J. (2017). The effect of size-segregated ambient particulate matter on Th1/Th2-like immune responses in mice. PLoS One 12, e0173158. https://doi.org/10.1371/journal.pone.0173158

Huang, H.L., Lee, W.M.G., Wu, F.S. (2016). Emissions of air pollutants from indoor charcoal barbecue. J. Hazard. Mater. 302, 198-207. https://doi.org/10.1016/j.jhazmat.2015.09.048

Huang, X., Ding, A., Gao, J., Zheng, B., Zhou, D., Qi, X., Tang, R., Wang, J., Ren, C., Nie, W., Chi, X., Xu, Z., Chen, L., Li, Y., Che, F., Pang, N., Wang, H., Tong, D., Qin, W., Cheng, W., et al. (2021). Enhanced secondary pollution offset reduction of primary emissions during COVID-19 lockdown in China. Natl. Sci. Rev. 8, nwaa137. https://doi.org/10.1093/nsr/nwaa137

Hvidtfeldt, U.A., Sørensen, M., Geels, C., Ketzel., M., Khan, J., Tjønneland, A., Overvad, K., Brandt, J., Raaschou-Nielsen, O. (2019). Long-term residential exposure to $\mathrm{PM}_{2.5}, \mathrm{PM}_{10}$, black carbon, $\mathrm{NO}_{2}$, and ozone and mortality in a Danish cohort. Environ. Int. 123, 265-272. https://doi.org/ 10.1016/j.envint.2018.12.010

International Energy Agency (IEA) (2016). Energy and Air Pollution: World Energy Outlook Special Report. https://www.iea.org/reports/energy-and-air-pollution (accessed August 2020).

Jiang, F., Liu, F., Lin, Q., Fu, Y., Yang, Y., Peng, L., Lian, X., Zhang, G., Bi, X., Wang, X., Sheng, G. (2019). Characteristics and formation mechanisms of sulfate and nitrate in size-segregated atmospheric particles from urban Guangzhou, China. Aerosol Air Qual. Res. 19, 1284-1293. https://doi.org/10.4209/aaqr.2018.07.0251

Jiang, S., Zhao, C., Fan, H. (2021). Toward understanding the variation of air quality based on a comprehensive analysis in Hebei province under the influence of COVID-19 lockdown. Atmos. 12, 267. https://doi.org/10.3390/atmos12020267

Kanawade, V.P., Tripathi, S.N., Chakraborty, A., Yu, H. (2020). Chemical characterisation of submicron aerosols during new particle formation in an urban atmosphere. Aerosol Air Qual. Res. 20, 1294-1305. https://doi.org/10.4209/aaqr.2019.04.0196

Karuna, M., Upadhyay, O., Saxena, D.K., Mahadeva Swamy, M., Majumder, S. (2017). Ambient air quality monitoring and prediction of air pollutants using ISCST3 and CALINE4 dispersion models for vehicular emissions at bareilly, Uttar Pradesh, India. IOSR J. Environ. Sci. Toxicol. Food Technol. 11, 12. https://doi.org/10.9790/2402-1112021429

Khan, M.F., Maulud, K.N.A., Latif, M.T., Chung, J.X., Amil, N., Alias, A., Mohd Nadzir, M.S., Sahani, M., Mohammad, M., Jahaya, M.F., Hassan, H., Jeba, F., Md Tahir, N., Abdullah, S.M.S. (2018). Physicochemical factors and their potential sources inferred from long-term rainfall measurements at an urban and a remote rural site in tropical areas. Sci Total Environ. 613614, 1401-1416. https://doi.org/10.1016/j.scitotenv.2017.08.025

Kotnala, G., Mandal, T.K., Sharma, S.K., Kotnala, R.K. (2020). Emergence of blue sky over Delhi due to coronavirus disease (COVID-19) lockdown implications. Aerosol Sci. Eng. 4, 228-238. https://doi.org/10.1007/s41810-020-00062-6

Kumari, P., Toshniwal, D. (2020). Impact of lockdown on air quality over major cities across the globe during COVID-19 pandemic. Urban Clim. 34, 100719. https://doi.org/10.1016/j.uclim.20 20.100719 
Lee, K.B., Kim, Y.J., Hong, Y.D. (2018). Real-time swarm search method for real-world quadcopter drones. Appl. Sci. 8, 1169. https://doi.org/10.3390/app8071169

Levy, J.I., Spengler, J.D., Hlinka, D., Sullivan, D., Moon, D. (2002). Using CALPUFF to evaluate the impacts of power plant emissions in Illinois: Model sensitivity and implications. Atmos. Environ. 36, 1063-1075. https://doi.org/10.1016/S1352-2310(01)00493-9

Liao, G. (2017). Shilin night market food court to ban melamine, disposable utensils. https://www.taiwannews.com.tw/en/news/3123836 (accessed August 2020).

Lin, C.Y, Li, Y.C, Amesho, K.T.T., Chou, F.C., Cheng, P.C. (2019). Characterization and quantification of $\mathrm{PM}_{2.5}$ emissions and $\mathrm{PAHs}$ concentration in $\mathrm{PM}_{2.5}$ from the exhausts of diesel vehicles with various accumulated mileages. Sci. Total Environ. 660, 188-198. https://doi.org/10.1016/j.sci totenv.2019.01.007

Lin, C.Y., Lai, C.Y., Chu, C.P. (2021). Air pollution diffusion simulation and seasonal spatial risk analysis for industrial areas. Environ. Res. 194, 110693. https://doi.org/10.1016/j.envres.2020. 110693

Lin, Y.C., Li, Y.C, Amesho, K.T.T., Shangdiar, S., Chou, F.C., Cheng, P.C. (2020a). Chemical characterization of $\mathrm{PM}_{2.5}$ emissions and atmospheric metallic element concentrations in $\mathrm{PM}_{2.5}$ emitted from mobile source gasoline-fueled vehicles. Sci. Total Environ. 739, 139942-139951. https://doi.org/10.1016/j.scitotenv.2020.139942

Lin, Y.C., Li, Y.C., Amesho, K.T.T., Chou, F.C., Cheng, P.C. (2020b). Filterable PM2.5, metallic elements, and organic carbon emissions from the exhausts of diesel vehicles. Aerosol Air Qual. Res. 20, 1319-1328. https://doi.org/10.4209/aaqr.2020.02.0081

Liu, C., Yang, C.Y., Zhao, Y.H., Ma, Z.W., Bi, J., Liu, Y., Meng, X., Wang, Y., Cai, J., Kan, H., Chen, R. (2016). Associations between long-term exposure to ambient particulate air pollution and type 2 diabetes prevalence, blood glucose and glycosylated hemoglobin levels in China. Environ. Int. 92-93, 416-421. https://doi.org/10.1016/j.envint.2016.03.028

Liu, J., Chen, Y., Chao, S., Cao, H., Zhang, A., Yang, Y. (2018). Emission control priority of PM2.5bound heavy metals in different seasons: A comprehensive analysis from health risk perspective. Sci. Total Environ. 644, 20-30. https://doi.org/10.1016/j.scitotenv.2018.06.226

Liu, Z., Ciais, P., Deng, Z., Lei, R., Davis, S.J., Feng, S., Zheng, B., Cui, D., Dou, X., Zhu, B., Guo, Rui, Ke, P., Sun, T., Lu, C., He, P., Wang, Yuan, Yue, X., Wang, Yilong, Lei, Y., Zhou, H., et al. (2020). Near-real-time monitoring of global $\mathrm{CO}_{2}$ emissions reveals the effects of the COVID-19 pandemic. Nat. Commun. 11, 5172. https://doi.org/10.1038/s41467-020-18922-7

Mahato, S., Pal, S., Ghosh, K.G. (2020). Effect of lockdown amid COVID-19 pandemic on air quality of the megacity Delhi, India. Sci. Total Environ. 730, 139086. https://doi.org/10.1016/j.scitoten v.2020.139086

McGuinn, L.A., Schneider, A., McGarrah, R.W., Ward-Caviness, C., Neas, L.M., Di, Q., Schwartz, J., Hauser, E.R., Kraus, W.E., Cascio, W.E., Diaz-Sanchez, D., Devlin, R.B. (2019). Association of long-term $\mathrm{PM}_{2.5}$ exposure with traditional and novel lipid measures related to cardiovascular disease risk. Environ. Int. 122, 193-200. https://doi.org/10.1016/j.envint.2018.11.001

Mesquita, S.R., van Drooge, B.L., Barata, C., Vieira, N., Guimaraes, L., Pina, B. (2014). Toxicity of atmospheric particle-bound PAHs: An environmental perspective. Environ. Sci. Pollut. Res. Int. 21, 11623-11633. https://doi.org/10.1007/s11356-014-2628-y

Mohd Nadzir, M.S., Ooi, M.C.G., Alhasa, K.M., Bakar, M.A.A., Mohtar, A.A.A., Nor, M.F.F.M., Latif, M.T., Hamid, H.H.A., Ali, S.H.M., Ariff, N.M., Anuar, J., Ahamad, F., Azhari, A., Hanif, N.M., Subhi, M.A., Othman, M., Nor, M.Z.M. (2020). The impact of Movement Control Order (MCO) during pandemic COVID-19 on local air quality in an urban area of Klang Valley, Malaysia. Aerosol Air Qual. Res. 20, 1237-1248. https://doi.org/10.4209/aaqr.2020.04.0163

Ojekunle, Z.O., Jinadu, O.O.E., Afolabi, T.A., Taiwo, A.M. (2018). Environmental pollution and related hazards at Agbara industrial area, Ogun State. Sci. Rep. 8, 6482. https://doi.org/10.10 38/s41598-018-24810-4

Oruko, R.O., Selvarajan, R., Ogola, H.J.O., Edokpayi, J.N., Odiyo, J.O. (2020). Contemporary and future direction of chromium tanning and management in sub Saharan Africa tanneries. Ecotoxicol. Environ. Saf. 133, 369-386. https://doi.org/10.1016/j.psep.2019.11.013

Pani, S.K., Chantara, S., Khamkaew, C., Lee, C.T., Lin, N.H. (2019). Biomass burning in the northern peninsular Southeast Asia: Aerosol chemical profile and potential exposure. Atmos. Res. 224, 180-195. https://doi.org/10.1016/j.atmosres.2019.03.031 
Prakash, B., Shobhan, M., Mahadeva, S., Mahesh, S. (2017). Prediction of air pollutant dispersion from point and line sources and validation of ISCST3 and Caline4 model data with observed values in the industrial area of Mysuru. Int. J. Innov. Res. Sci. Eng. 6, 18333-18350. https://doi.org/10.15680/IJIRSET.2017.0609121

Rodopoulou, S., Chalbot, M.C., Samoli, E., Dubois, D.W., San Filippo, B.D., Kavouras, I.G. (2014). Air pollution and hospital emergency room and admissions for cardiovascular and respiratory diseases in Dona Ana County, New Mexico. Environ. Res. 129, 39-46. https://doi.org/10.1016/ j.envres.2013.12.006

Rzeszutek, M., Szulecka, A., Oleniacz, R., Bogacki, M. (2017). Assessment of the AERMOD dispersion model over complex terrain with different types of meteorological data: Tracy Power Plant experiment. In: Paper Presented at the E3S Web of Conferences.

Salje, H., Gurley, E.S., Homaira, N., Ram, P.K., Haque, R., Petri, W., Moss, W.J., Luby, S.P., Breysse, P., Azziz-Baumgartner, E. (2014). Impact of neighborhood biomass cooking patterns on episodic high indoor particulate matter concentrations in clean fuel homes in Dhaka. Bangladesh Indoor Air 24, 213-220. https://doi.org/10.1111/ina.12065

Santoso, M., Hopke, P.K., Permadi, D.A., Damastuti, E., Lestiani, D.D., Kurniawati, S., Khoerotunnisya, D., Sukir, S.K. (2021). Multiple air quality monitoring evidence of the impacts of large-scale social restrictions during the COVID-19 pandemic in Jakarta, Indonesia. Aerosol Air Qual. Res. 21, 200645. https://doi.org/10.4209/aaqr.200645

Scire, J.S., Strimaitis, D.G., Yamartino, R.J. (2000). A user's guide for the CALPUFF dispersion model. Earth Tech. Inc., USA.

Song, A., Meng, J., Zhou, R., Li, Z., Li, Y., Chen, M., Hou, Z., Yan, L., Wang, Y. (2021). Characteristics and sources of single particles in the urban Liaocheng of North China during the heating period. Aerosol Air Qual. Res. 21, 210144. https://doi.org/10.4209/aaqr.210144

Stabile, L., Fuoco, F.C., Marini, S., Buonanno, G. (2015). Effects of the exposure to indoor cookinggenerated particles on nitric oxide exhaled by women. Atmos. Environ. 103, 238-246. https://doi.org/10.1016/j.atmosenv.2014.12.049

Sulong, N.A., Latif, M.T., Khan, M.F., Amil, N., Ashfold, M.J., Wahab, M.I.A., Sahani, M. (2017). Source apportionment and health risk assessment among specific age groups during haze and non-haze episodes in Kuala Lumpur, Malaysia. Sci Tot Environ. 601-602, 556-570. https://doi.org/10.1016/j.scitotenv.2017.05.153

Sun, Y.M., Wang, S.T., Huang, K.W. (2012). Hygiene knowledge and practices of night market food vendors in Tainan City. Taiwan Food Control 23, 159-164. https://doi.org/10.1016/j.foodcont. 2011.07.003

Sun, Z., Duan, F., Ma, Y., He, K., Zhu, L., Ma, T. (2019). Heavy particulate matter pollution during the 2014-2015 winter in Tianjin, China. Aerosol Air Qual. Res. 19, 1338-1345. https://doi.org/ 10.4209/aaqr.2018.04.0121

Uroš, L., Domen, M., David, J. (2019). Predictive analytics of $\mathrm{PM}_{10}$ concentration levels using detailed traffic data. Transp. Res. Part D: Transp. Environ. 67, 131-141. https://doi.org/10.101 6/j.trd.2018.11.015

Vicente, E.D., Vicente, A., Evtyugina, M., Carvalho, R., Tarelho, L.A.C., Oduber, F.I., Alves, C. (2018). Particulate and gaseous emissions from charcoal combustion in barbecue grills. Fuel Process. Technol. 176, 296-306. https://doi.org/10.1016/j.fuproc.2018.03.004

Vu, T.V., Shi, Z., Cheng, J., Zhang, Q., He, K., Wang, S., Harrison, R.M. (2019). Assessing the impact of clean air action on air quality trends in Beijing using a machine learning technique. Atmos. Chem. Phys. 19, 11303-11314. https://doi.org/10.5194/acp-19-11303-2019

Wakeling, D., Passant, N.R., Murrells, T.P., Pang, Y., Thistlethwaite, G., Walker, C., Garcia, J.M.R., Webb, J., Brown, P., Del Vento, S., Misra, A., Hobson, M., Pridmore, A., Dore, C., Misselbrook, T. (2016). UK informative inventory report (1990-2014). National Atmospheric Emissions Inventory, UK. https://naei.beis.gov.uk/reports/reports?report_id=896

Wang, F., Wang, J., Han, M., Jia, C., Zhou, Y. (2019). Heavy metal characteristics and health risk assessment of $\mathrm{PM}_{2.5}$ in students' dormitories in a university in Nanjing, China. Build. Environ. 160, 106206. https://doi.org/10.1016/j.buildenv.2019.106206

Watson, S.A. (2010). Lubricant-derived ash - in-engine sources and opportunities for reduction. Doctoral dissertation, Massachusetts Institute of Technology, USA.

Wei, W.C., Lin, H.J., Lim, Y.P., Chen, C.S., Chang, C.Y., Lin, C.J., Chen, J.J.Y., Tien, P.T., Lin, C.L., 
Wan, L. (2019). PM 2.5 and $\mathrm{NO}_{x}$ exposure promote myopia: Clinical evidence and experimental proof. Environ. Pollut. 254, 113031. https://doi.org/10.1016/j.envpol.2019.113031

Wesely, M.L., Doskey, P.V., Shannon, J. (2002). Deposition Parameterizations for the Industrial Source Complex (ISC3) Model (ANL/ER/TR-01/003; W-31-109-Eng-38; Other: 62977 United States 10.2172/1260839 Other: 62977 ANL English). https://www.osti.gov/servlets/purl/1260 839

Xu, K., Cui, K., Young, L.H., Hsieh, Y.K., Wang, Y.F., Zhang, J., Wan, S. (2020). Impact of the COVID19 event on air quality in central China. Aerosol Air Qual. Res. 20, 915-929. https://doi.org/10. 4209/aaqr.2020.04.0150

Zhang, N., Han, B., He, F., Xu, J., Zhao, R.J., Zhang, Y.J., Bai, Z.P. (2017). Chemical characteristic of $\mathrm{PM}_{2.5}$ emission and inhalational carcinogenic risk of domestic Chinese cooking. Environ. Pollut. 227, 24-30. https://doi.org/10.1016/j.envpol.2017.04.033

Zhao, P., Yu, K.P., Lin, C.C. (2011). Risk assessment of inhalation exposure to polycyclic aromatic hydrocarbons in Taiwanese workers at night markets. Int. Arch. Occup. Environ. Health. 84, 231-237. https://doi.org/10.1007/s00420-010-0551-1

Zhao, Y., Chen, C., Zhao, B. (2019). Emission characteristics of PM2.5-bound chemicals from residential Chinese cooking. Build. Environ. 149, 623-629. https://doi.org/10.1016/j.buildenv. 2018.12.060 